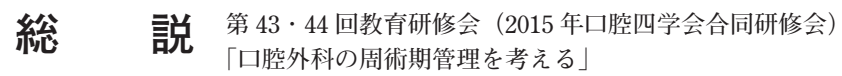

\title{
周術期オーラルマネジメントの実際
}

\author{
岸本裕充
}

\section{Practice of perioperative oral management}

\author{
KISHIMOTO Hiromitsu
}

\begin{abstract}
With the revision in fiscal year 2012 of the healthcare insurance, "the perioperative oral management fee" has been newly established, which is expected to reduce the complications after cancer, cardiac and other surgeries. Possible oral-related complications during perioperative period include 1) damage to teeth during endotracheal intubation, 2) pressure ulcer due to compression of orally-intubated endotracheal tube, 3) postoperative pneumonia, 4) surgical site infection of oropharynx, and others. Also, there is a potential risk of developing foreign material infections due to bacteremia from the oral cavity as the periodontitis remains there. Such risks are found in surgeries where the materials such as prosthetic valves and artificial joints are installed inside the body.

The term "perioperative oral care" is often heard. In order to prevent the above-mentioned complications, however, the author suggests dentists be expected to "not only provide oral care but also put the oral management $(\mathrm{OM})$ into practice". In addition to the oral Cleaning which is narrowly defined as oral care, it is important for OM here to include the total 5 elements, which are Rehabilitation for mastication and swallowing, Education of patients and medical staff, accurate oral Assessment, and dental Treatment which includes tooth extractions and adjusting dentures. The concept of $\mathrm{OM}$ is that fully achieving above 5 elements enables one to Eat or Enjoy food. The 6 initials starting from Cleaning and Rehabilitation to Eat or Enjoy read CREATE in the order described, and the goal of OM is to "CREATE oral cavity that can eat well".

Therefore, the oral-related perioperative complications can be prevented by "improving one's oral environment in good condition", while considering priority of above 5 elements based on a concept of OM in a limited short perioperative period.
\end{abstract}

Key words: oral management (口腔管理), oral care (口腔管理), assessment (評価), dental treatment (蒾科治療), perioperative (周術期の)

\section{緒言}

平成 24 年度の診療報酬改定で「周術期口腔機能管理料 (周管)」が新設され，がんや心臓外科などの手術後の合併 症を予防ないしは低減することが期待されている。この周 管のさらなる普及を期待されて, 平成 26 年度の改定では, 歯科での術前の周管が増点されたことに加え，「医科点数 表」に周管を受けた患者の「手術料への加算」が収載され， さらに平成 28 年度の改定で, その加算が 100 点から 200

兵庫医科大学柬科口腔外科学講座

(主任：岸本裕充教授)

Department of Dentistry and Oral Surgery, Hyogo College of Medicine (Chief: Prof. KISHIMOTO Hiromitsu)
点に増点された。

医療保険制度に打ける周管では, 放射線治療とがん化学 療法による口腔に関連する合併症への対応, さらに平成 28 年度の改定では緩和ケアを受ける患者も対象に含まれるよ うになった。しかしながら, 本来「周術期」は手術前後の 限定された期間を指す用語であり，本稿においては，この 手術前後に打ける当科での取り組みに限定して解説する.

\section{周管の対象患者}

医療保険制度においては「全身麻酔下で実施される，頭 頸部領域, 呼吸器領域, 消化器領域等の悪性腫瘍の手術, 臓器移植手術又は心臓血管外科手術等」とある。このなか 


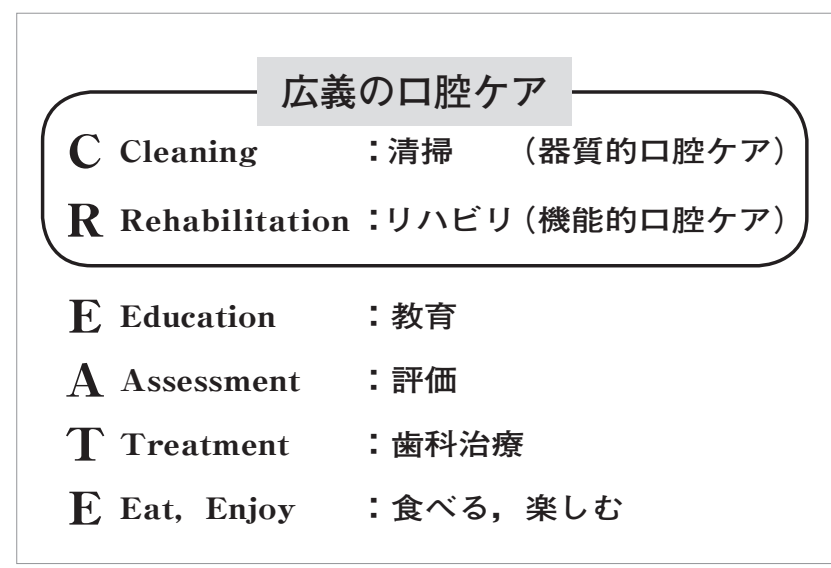

図 1 オーラルマネジメントの構成要素 CREATE

Cleaning, Rehabilitationから Eatまたは Enjoyまでの 頭文字 6 つを順に並べると CREATEになる.

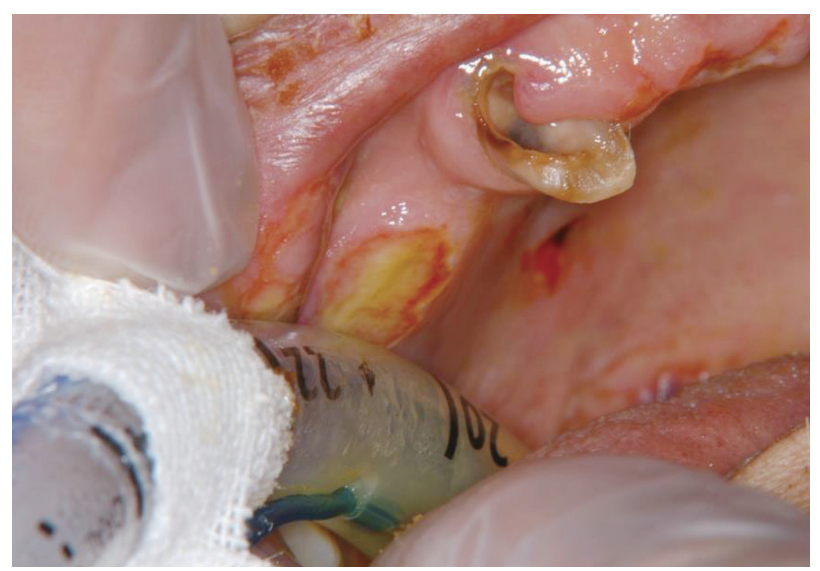

写真 1 気管チューブによる裖瘡性潰瘍 裖瘡性潰瘍にステロイド外用薬を使用すると， 2 次感染, 治癒の遷延のリスクがある.

後述する「口腔環境の整備」を図ることで, 周術期の口腔 に関連する合併症を予防・低減できる。

\section{評価の重要性} ベきであろう。

口腔に関連する合併症として 11 ) 気管挿管時の蒾の損 傷，2）経口気管チューブの圧迫による褛痆性潰瘍，3）術 後肺炎，4） 口腔咽頭の創部感染 (SSI; surgical site infection），などが考えられる。また，人工弁や人工関節など， 異物を留置する手術では, 遠隔部位感染 (RI; remote infection）として，㐘周炎など口腔に由来する菌血症によって 将来的に感染を生じるリスクがある。

\section{ロ腔ケアからオーラルマネジメントヘ}

「周術期の口腔ケア」という用語も見聞されるが，上記 のような合併症を予防するために茵科医師に望まれている のは，「口腔ケアに留まらず，オーラルマネジメント（OM; oral management）の実践である」と筆者は提唱してい $ろ^{1)}$.この $\mathrm{OM}$ とは, 狭義の口腔ケアとされる口腔清掃 (Cleaning) に加えて，咀嚼や臙下のリハビリ（Rehabilitation)，患者や医療従事者への教育（Education），的確な口 腔の評価 (Assessment)，さらに抜茵や義茵の調整などの 茵科治療 (Treatment), 以上の 5 つの要素が揃うことが重 要であり, これら 5 つの要素を適切に達成できれば，おい しく食べる (Eat)，もしくは，楽しむ (Enjoy)ことが可能 となる，という概念である(図 1)。

Cleaning, Rehabilitationから Eatまたは Enjoyまでの 頭文字 6つを順に並べると CREATE で，「食べられる口を CREATE (つくる)」が OMの目標であり，そのためには
OM の構成要素である CREATE の真ん中の A である「評 価」は，OMの他の要素である清掃，リハビリ，教育，治 療のベースとなる。評価や診断が詥っていれば，清掃，リ ハビリ，教育，治療のいずれもが不適切になりうる。

「清掃・教育」で例を挙げれば，「柬ブラシの使用を安易 に禁止」がある，歯肉出血の原因が㐘周病であるのに，抗 血栓薬や血小板減少の影響を過大評価され，しばしば㐘ブ ラシの使用が禁止されている。㐘ブラシの使用の手技に よっては菊肉からの出血を助長するが, 㐘垢を除去しなけ れば，歯周病に由来する柬肉出血は改善しない．

「リハビリ」では, 漫然と「直接嚥下訓練を延期・絶食 を継続」がある、機能的に直接嚥下訓練を開始可能な状態 に回復しているにもかかわらず，䛊嚥を過剩に恐れて訓練 をステップアップされない事例が見聞される，絶食状態は 口腔の自浄性が低下するため, 不顕性誤嚥を生じる患者で は，誤嚥を生じた際に肺炎を発症するリスクは高い。また， リハビリの遅滞は, 廃用の進行を来し，回復をさらに困難 にさせる，

抜茵など「菌科治療」が必要な状況であるにもかかわら ず，菌科治療が必要との評価がなされていない事例は多く ある。菌科治療に限らず，医科も含めた「治療」における 処方に打いて,「口腔粘膜の裖瘡性潰瘍にステロイド外用 薬を塗布」というのは不適切である（写真 1)。気管チュー ブやバイトブロックによる局所性圧迫が原因であるのに， 口内炎と診断して処方されることが多い。裖瘡性潰瘍にス 


\begin{tabular}{|c|c|}
\hline 予防的口腔ケア一主に柬科衛生士が担当 & $\begin{array}{l}\text { CRE } \\
\text { ATE }\end{array}$ \\
\hline $\begin{array}{l}\text { ・目空衛生指導：セルフケア技術の向上 } \\
\text { 柬ブラシ } \\
\text { 補助清掃用具 } \\
\text { (フロス, 㐘間ブラシ , ポイントタフトブラシ) } \\
\text { 保湿 (ドライマウス対策 : 保湿=加湿十蒸発予防) }\end{array}$ & $\mathrm{E}$ \\
\hline ·術者磨き*) & $\mathrm{C}$ \\
\hline 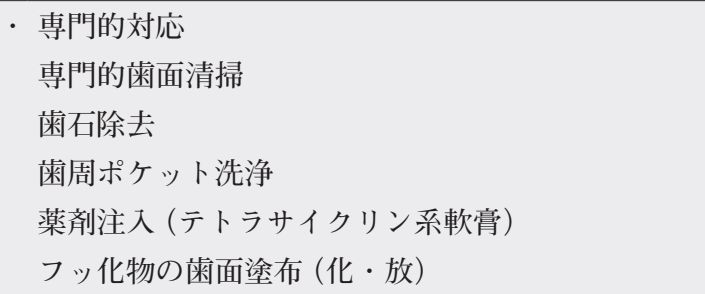 & $\begin{array}{l}\mathrm{T} \\
\text { C } \\
\text { C }\end{array}$ \\
\hline $\begin{array}{l}\cdot \text { 口腔粘膜に関する指導 }(\text { 化・放) } \\
\text { 感染予防・疼痛対策 }\end{array}$ & $\mathrm{E}$ \\
\hline - 食事指導 食形態指導·味覚障害への対応 & $\mathrm{E}$ \\
\hline
\end{tabular}

\begin{tabular}{|c|}
\hline 㐘科治療 一柬科医師が担当 $[\mathrm{T}]$ \\
\hline う蝕治療 \\
\hline (暫間) 充填 \\
\hline 根管处置 \\
\hline 義柬の調整／修理 \\
\hline 拔㐘处置 \\
\hline 柬や補綴物の形態修正 \\
\hline 口腔がん患者で腫瘍や皮弁の圧迫が予想されるもの (手) \\
\hline 口腔粘膜炎の原因となり得る鋭縁 (化・放) \\
\hline 動摇㐘の暫間固定 (手) \\
\hline 床装置の作製 \\
\hline プロテクター (手), シーネ (化), スペーサー（放） \\
\hline 金属製補綴物除去／TEKへの置換（放） \\
\hline
\end{tabular}

*) 患者が使用する茵ブラシ，柬間ブラシなどを使って，柬科衛生士が菌面清掃することで, 効率よく茵垢を

除去できるとともに, ブラシの当たる感覚 (圧や速度など) を覚えられるというメリットがある ※手: 手術療法, 化: 化学療法, 放: 放射線治療, とくに記載がないものはすべての療法に拈いて必要 ※ $\mathrm{C}$ (Cleaning), R (Rehabilitation), E (Education), A (Assessment), T (Treatment)

図 2 口腔環境の整備

主に柬科衛生士が担当する予防的口腔ケアと柬科治療に分類できる。放射線治療, 化学療法時のものも含む. 文献 2 ) から引用.

テロイド外用薬を使用すると, 2 次感染, 治癒の遷延のリ スクがある。

口腔に関しては歯科以外の職種から歯科へ「丸投げ」と なりやすい. 患者が OMの中心であることを常に意識し， 患者に関わるすべての職種が患者の口腔にも関心をもって 口腔を観察・評価し, 問題点の発見や, 何らかのアドバイ スできれば理想的である。歯科以外の職種は, 後述する口 腔アセスメントチャート (COACH; clinical oral assessment chart）を用いて，口腔を評価していただきたい.

\section{口腔環境の整備}

的確に口腔の状態や機能を評価すると, 口腔ケア方法の 見直しや，口腔ヶアだけは不充分で，抜柬や義柬の調整な どの歯科治療が必要な場合がしばしばである。周術期の $\mathrm{OM}$ に打ける「口腔環境の整備」(図 2) $\left.{ }^{2}\right)$ とは, 口腔の 清浄性を保ちやすくするために, 口腔清掃を実施しやすく する, いわゆる「広義のプラークコントロール」と捉える こともできる。口腔衛生指導（術者磨きも含む）を実施し， 必要であれば柬石除去や専門的柬面清掃を実施する。菌周 病による歯肉出血を改善させるための柬周ポケット洗浄も
積極的に取り入れている.

歯科治療としては, 前述の「口腔に関連する合併症」5 つの予防を念頭に, 動摇菊への対応としての抜菊や暫間固 定, マウスプロテクター(保険給付外), う蝕部分への（暫 間) 充填, 義苗の調整・修理・追補（抜柬した場合に限ら ず久損があれば) の実施頻度が比較的高い。

\section{周管の実際}

気管挿管時の歯の損傷の予防を第一目標とするなら, 全 身麻酔下で手術を受ける予定の患者すべてを対象とするこ とは悪くないかもしれない。しかしながら, 現状において， 手術を受ける病院に併設される歯科では, マンパワーの面 で難しい。また，がん検診と同様に「費用対効果」を考え れば，「術後肺炎や創部感染などを生じるリスクの高い患 者を優先的に」が現実的であろう.

当科では, 口腔外科手術は別にして, 10 年以上前から 食道癌手術と人工并置換手術の 2 つを最優先して周管に取 り組んできた。いずれも開胸手術で, 口腔に問題がある患 者が多く, とくに食道癌手術では術後肺炎を発症する頻度 が高い. 人工弁置換手術を受けた患者では, 感染性心内膜 
表 1 食道癌手術 (月曜) 後経過および肺炎の発生

\begin{tabular}{lrrrrrr}
\hline & \multicolumn{2}{c}{ 対照群 } & \multicolumn{2}{c}{ プラークフリー群 (日曜) } & 簡略プラークフリー群 (金曜) \\
\hline 気管挿管期間 (日) & $3.3 \pm 3.5$ & $1 \sim 13$ & $2.3 \pm 1.7$ & $1 \sim 7$ & $1.8 \pm 2.4$ & $1 \sim 10$ \\
ICU 収容日数 & $7.3 \pm 5.3$ & $2 \sim 23$ & $6.0 \pm 3.5$ & $2 \sim 17$ & $3.4 \pm 3.4$ & $1 \sim 20$ \\
発熱日数 (38.0 $\mathrm{C}$ 以上) & $3.1 \pm 3.5$ & $0 \sim 13$ & $2.2 \pm 3.2$ & $0 \sim 12$ & $1.1 \pm 1.4$ & $0 \sim 7$ \\
\hline 肺炎 & $20 \%$ & $(3 / 15)$ & $8.7 \%$ & $(2 / 23)$ & $4.1 \%$ & $(2 / 49)$ \\
MRSA の検出 & $20 \%$ & $(3 / 15)$ & $0 \%$ & $(0 / 23)$ & $0 \%$ & $(0 / 49)$ \\
\hline
\end{tabular}

文献 4 ） から引用

炎を予防するために，抜柬などの観血的処置時だけでなく 日常から菌周炎に由来する菌血症を予防することが重要と 考えられて打り ${ }^{3)}$ ，理論上は人工并置換手術前に柬科治療 を済ませて扔くことが望ましい．

人工弁置換手術後の感染性心内膜炎は希少であるため, 周管の成果を実感しにくいが，食道癌手術では術後肺炎を 減少させることができた ${ }^{4}$ ) ので，概略を紹介する（表 1).

食道癌手術後には，気管插管のまま ICU に収容される ことが一般的で，テープで固定された気管チューブやバイ トブロックが口腔に存在し，鎮静下にあるため患者の協力 は得られず，看護師による口腔ケアが難しい要因が重なっ ていた．これに，歯の動摇や㐘肉出血などの悪条件が加わ ることも珍しくなかった。

菌科口腔外科の介入開始前の術後肺炎の発症頻度は $20 \%$ （3/15）であった。手術のために入院してからの数日間に, 動摇菌の抜菌やう蝕部分への暫間充填, 茵肉縁上の菌石除 去などの「口腔環境の整備」を図り，手術の前日の絶食開 始後に専門的歯面清掃を行い, 㐘垢染色液で歯肉縁上のプ ラークフリーの達成を確認した。この介入によって, 術後 肺炎は $8.7 \%(2 / 23)$ に減少の手ごたえを得たが，当院の食 道癌手術は月曜日に割り当てられて打り，休日である日曜 日の夕方に「プラークフリー法」を実施することを見直す ことにした。

「簡略プラークフリー法」として, 手術の前の週の金曜 日か土曜日に同様にプラークフリーを達成した後は, 手術 当日の朝まで患者自身によるセルフケアに委ねることにし た。専門的菌面清掃を実施してから手術前の時間が長くな ることから，術後肺炎の予防効果が低下することを危惧し たが，予想に反して術後肺炎は 4.1\%（2/49）にまで減少で きた。

推測の域を出ないが，手術の前日の絶食開始後に専門的 柬面清掃を行う方が，その時点での比較では菌垢の付着は 少ないであろうが, 手術当日の朝のセルフケアは不充分で あった可能性がある。一方，七ルフケアを強化したことで，
手術室入室時には，「簡略プラークフリー法」の方が口腔 の状態は良かったのかもしれない.

手術前日の専門的茵面清掃でなくても，術後肺炎の予防 に有効な可能性が示されたことから，入院前に患者が「か かりつけ菌科」で周管を受けることでも，七ルフケア能力 を向上できれば，術後肺炎の予防に寄与できると思われた。

\section{周管を普及させるには}

医療保険制度における周管では，医師からの依頼が起点 となる。㐘科治療が必要など，口腔に問題を有する患者を， 医師や看護師が抽出するのは容易ではないので，患者との 医療面接で確認すべき事項を列挙した $(\text { 図 } 3 \text { 左 })^{5)}$.

一方, 術後肺炎や創部感染などを発症しやすいか否かは, 手術の術式や患者の全身状態（感染防御能，呼吸機能など） から医師や看護師が予測しやすい (図 3 右)。たとえば,「術 後肺炎」では, 開胸手術などによる咳嗽困難, 器質的打よ び機能的臙下障害, 反回神経麻瘁の存在, 長期の絶食によ る口腔の自浄性の低下はハイリスクであり, 誤嚥性肺炎の 特殊型とも言える「人工呼吸器関連肺炎」では気管挿管の 長期化が問題となる ${ }^{6)}$. 前述の食道癌手術では, これらの 多くが該当し，術後肺炎を生じやすい。

上述のように「医師からの依頼が起点」が起点となるが， 「かかりつけ茵科」を受診中の患者が，何らかの手術を受 ける予定，という場面も決して珍しくはない，この場合は， 歯科から医科へ病状照会の形で，手術などの実施計画や基 礎疾患などの状態を問い合わせれば，周管を開始できる.

\section{ロ腔のバイタルサイン}

OMに打いて，柬科では「専門的な評価」を担い，菌科 以外の職種は「口腔のバイタルサイン」7）を意識して評価 すべき, と提唱している。これは，口腔の「清浄度」と「湿 潤度」を, 体温や血圧, 脈拍数と同様に, 身体の一部とし 
歯科的ハイリスク (口腔に問題がある) にあてはまる患者

むし㐘や柬周病を未治療で放置している：歯痛・㐘 肉腫脹や出血〈既往も含め〉, 歯の動摇, 口臭など

$\checkmark 1$ 年以上歯科は受診していない (㐘石が多く付着しているかも)

㐘みがきの習慣がない, または, あまり㐘をみが かない

$\square$ 㐘の欠損が多い(例：60 歳で残存蒾が 20 本未満), 柬の欠損を放置している（義菊を使ってない）

唾液が少ない，口が乾きやすい

\section{感染症などの合併症を} 生じやすい患者

感染防御能が低下: 造血幹細胞移植, 抗腫瘍薬 - 免 疫抑制薬などの使用

$\square$ 䛊嚥しやすい：開胸手術, 反回神経麻痺, 通過障害, 鎮静・意識障害など

口腔・咽頭に手術創がある

長期の気管挿管：咳反射の減弱・閾值克進

絶食

顎骨壊死のリスク：顎骨への放射線，ビスフォス フォネート薬の投与

図 3 周管の対象として優先すべき患者

口腔に問題がある可能性の高い患者と, 感染症などの合併症を生じやすい患者, という両面から患者を選択する。文献 5 ) から引用.

\begin{tabular}{|c|c|c|c|c|c|c|}
\hline & $\bigcirc$ & $\begin{array}{l}\text { 問題なし } \\
\text { 現状のケア方法を継続 }\end{array}$ & $\triangle$ & $\begin{array}{l}\text { 要注意 } \\
\text { 改善がなければ専門職への } \\
\text { アセスメントの依頼を検討 }\end{array}$ & $x$ & $\begin{array}{l}\text { 治療, 積極的な専門的介入 } \\
\text { が必要 }\end{array}$ \\
\hline 開 口 & \multicolumn{2}{|c|}{ ケア時に容易に開口する } & \multicolumn{2}{|c|}{$\begin{array}{l}\text { 開口には応じないが徒手的に } \\
2 \text { 横指程度開口可 }\end{array}$} & \multicolumn{2}{|c|}{$\begin{array}{l}\text { くいしばりや顎関節の拘縮のため } \\
\text { 開口量が } 1 \text { 横指以下 }\end{array}$} \\
\hline 口 臭 & な & & 口腔 & 二近づくと口臭を感じる & 室内 & こ口臭由来の臭いを感じる \\
\hline 流 涎 & な & & 嚥下 & 射の低下を疑うが, 流涎なし & あり & (嚥下反射の低下による) \\
\hline $\begin{array}{l}\text { 口腔乾燥 } \\
\text { 度·唾液 }\end{array}$ & \multicolumn{2}{|c|}{$\begin{array}{l}\text { (グローブをつけた) 手指での粘膜 } \\
\text { の触診で抵抗なく滑る唾液あり }\end{array}$} & \multicolumn{2}{|c|}{$\begin{array}{l}\text { 摩擦抵抗が少し増すが粘膜にくっ } \\
\text { つきうにはならない } \\
\text { 唾液が少なく，ネバネバ }\end{array}$} & \multicolumn{2}{|c|}{$\begin{array}{l}\text { 明らかに抵抗が増し粘膜にくっつ } \\
\text { きそうになる } \\
\text { 唾液が少なく, カラカラ }\end{array}$} \\
\hline 柬·義柬 & \multicolumn{2}{|c|}{$\begin{array}{l}\text { きれいで歯垢・食物残渣なし } \\
\text { 動摇する柬がない }\end{array}$} & \multicolumn{2}{|c|}{$\begin{array}{l}\text { 部分的に蒾垢や食物残渣がある動 } \\
\text { 摇歯があるがケアの妨げにならな } \\
\text { い程度 }\end{array}$} & \multicolumn{2}{|c|}{$\begin{array}{l}\text { 歯垢や歯石が多量に付着 } \\
\text { 抜けそうな菊がある }\end{array}$} \\
\hline \multirow[b]{2}{*}{ 舌 } & \multicolumn{2}{|c|}{ ピンク・潤いがある・污染なし } & \multicolumn{2}{|c|}{ 乾燥・発赤など色調の変化 } & \multirow{4}{*}{\multicolumn{2}{|c|}{$\begin{array}{l}\text { 自然出血・潰瘍・カンジダ } \\
\text { 気道分泌物・剝離上皮・凝血塊 } \\
\text { などが目立ち, 強固に付着 }\end{array}$}} \\
\hline & \multicolumn{2}{|c|}{ 糸状乳頭がある } & \multicolumn{2}{|c|}{$\begin{array}{l}\text { 糸状乳頭の延長 (舌苔), } \\
\text { 消失 (平滑舌) }\end{array}$} & & \\
\hline 口 唇 & \multicolumn{2}{|c|}{ 平滑 (亀裂なし) } & \multicolumn{2}{|c|}{ 亀裂あり, 口角炎 } & & \\
\hline 歯 肉 & \multicolumn{2}{|c|}{$\begin{array}{l}\text { 引き締まっている } \\
\text { (スティップリング) }\end{array}$} & \multicolumn{2}{|c|}{ 腫脹, ブラッシング時に出血 } & & \\
\hline
\end{tabular}

図 4 口腔アセスメントチャート $\mathrm{COACH}$ (clinical oral assessment chart)

㐘科以外の職種は「口腔のバイタルサイン」である「清浄度」と「湿潤度」に, 開口や流涎などの機能的評価も加えて評価する。文献 8 ) から引用.

て，適宜評価しよう，というものである。これらに開口や 流涎などの機能的評価も加えた $\mathrm{COACH}$ を基準に使用して いる(図 4) ${ }^{8}$ ).

「口臭」は清浄度と湿潤度の両者を反映し，「㐘・義㐘」
および「粘膜」の清浄度と,「口腔乾燥度・唾液」で湿潤 度を評価する。粘膜を舌, 口唇, 歯肉に分類し, それぞれ の基準を設定してはいるが, 粘膜全般を見渡して, 污染物 や粘膜炎などの有無を確認することによって, 記録の省力 
化を罒ることを意罒している。

口腔のバイタルサインである清浄度と湿潤度を柬科以外 の職種がモニターする，という習慣が確立すれば，「きれ いで潤いのある口腔」を維持できるようにケアする，とい う目標設定が明確になる。また， $\mathrm{COACH}$ の各項目に改善 がなければ，その評価そのものや実施してきたケアが正し いのか, (歯科) 治療が必要ではないか, などを確認する ために，専門的介入の検討が必要であろう.

どこの施設でも柬科以外の職種の口腔の評価能力には個 人差が大きいのが実情であろうが，専門的介入によって評 価やケアに何らかの問題が判明した際には,「次に活かす」 を意識して，CREATEの真ん中の教育 (E) と評価 (A) であ る，評価方法を教育する絶好の機会と考えるべきであろう.

\section{周術期の OM における時間のやりくり}

周術期の OM においては，「時間のやりくり」が問われ る局面がまれにある。たとえば，「㐘根破折があるので・ 動摇が強いので抜柬」というような「抜柬の基準」自体は 柬科医師によってあまり大きな差はない（現実には，㐘科 医師の専門領域による差はありうる）が，抜㐘を手術まで に済ませるか否か，という「判断」には，OMの経験によ る差があると思われる。とくに, 心蔵外科での人工弁や, 整形外科での人工関節のような異物を留置する手術では, 抜㐘などに伴う菌血症を手術「後」に生じないようにする ため, できるだけ手術「前」に菌血症を生じるリスクの高 い処置を済ませるべきであろう。

周管における口腔環境の整備は, がんなどの治療を開始 する前に完了できれば，それに越したことはない。しかし ながら, 全身麻酔の手術に伴う口腔に関連する合併症を予 防する，という目的だけであれば，移植手術や人工物を留 置する場合を除いて, 手術前の整備は必要最小限とし, 残 りは手術後に再開しても問題ないことが多い.

この「手術後に再開」は非常に重要であり, 将来的にが んの再発や転移を生じた際に, 口腔環境の整備に手間取っ て, がん化学療法の開始が遅れる, というようなことがな いようにしたい。「口腔粘膜炎」や「柬性感染症の急性化」
を生じやすいレジメンのがん化学療法を実施する可能性が ある, 骨転移を生じてビスフォスフォネートやデノスマブ を投与する可能性がある, というような患者は, 周管の対 象として相応しいであろう(図 3 右).

\section{結語}

周術期の合併症を低減するための OM について概説し た. 手術前から開始することが重要であり, 歯科以外の職 種から効率良く周管の依頼が来るシステムが普及すること を願う。

本論文に関して，開示すべき利益相反状態はない.

\section{引用文献}

1) 岸本裕充, 大石善也, 他：口腔ケアからオーラルマ ネジメントへー医科柬科連携の重要性一。医事新 報 4459: 54-58, 2009.

2 ）大野友久, 福永暁子, 他：がん患者に対するオーラ ルマネジメント。岸本裕充, 菊谷 武, 他 編著; オーラルマネジメントに取り組もう。高齢期と周術 期の口腔機能管理, デンタルダイヤモンド社, 東京, 2012, 88-99 頁.

3 ) 岸本裕充, 坂本春生 : 感染性心内膜炎に対する最新 予防ガイドライン - AHA2007. 日口腔感染症会誌 15: 3-9, 2008.

4 ) 河田尚子, 岸本裕充, 他: 食道癌術後肺炎予防のた めの術前オーラルマネジメント。日口腔感染症会誌 17: 31-34, 2010.

5 ) 岸本裕充：新しい「周術期口腔機能管理」を活用 するための A to Z. エキスパートナース 28: 32-37, 2012.

6 ）岸本裕充：ICU で経口気管挿管中の患者に対する口 腔ケア. 人工呼吸 32: 37-43, 2015.

7 ) 岸本裕充: 口腔乾燥. 若林秀隆, 藤本篤士 編著; サルコペニアの摂食・嚥下障害 リハビリテーショ ン栄養の可能性と実践. 第 1 版, 医蒾薬出版, 東京, 2012, 208-212 頁.

8 ) 岸本裕充: $\mathrm{COACH}$ (Clinical Oral Assessment CHart). 岸本裕充 編著; 口腔アセスメントカード. 初版, 学研メディカル秀潤社, 東京, 2013, 2 頁. 